\title{
PENUNDAAN PEMILIHAN KEPALA DAERAH PADA MASA PANDEMI COVID-19 DALAM PERSPEKTIF HUKUM ADMINISTRASI NEGARA
}

\author{
in The Perspective of Administrative Law) \\ Wicipto Setiadi \\ Dosen Fakultas Hukum UPN Veteran Jakarta \\ e-mail: wiciptosetiadi@upnvj.ac.id \\ Citraresmi Widoretno Putri \\ Dosen Fakultas Hukum UPN Veteran Jakarta \\ e-mail: citraresmikimifira@upnvj.ac.id
}

(Postponement of Regional Head Elections During The Covid-19 Pandemic

\begin{abstract}
Abstrak
Pemilihan umum merupakan cara untuk memilih wakil-wakil rakyat secara demokratis. Dengan adanya pandemi Covid-19 maka pemilihan kepala daerah Tahun 2020 ditunda. Hal ini diatur dalam Undang - Undang Nomor 6 Tahun 2020 dan Keputusan Komisi Pemilihan Umum Republik Indonesia Nomor: 179/PL.02-Kpt/01/KPU/III/2020 tentang Penundaan Tahapan Pemilihan Gubernur Dan Wakil Gubernur, Bupati Dan Wakil Bupati, Dan / Atau Walikota Dan Wakil Walikota Tahun 2020 Dalam Upaya Pencegahan Penyebaran Covid-19. Penelitian ini menggunakan penelitian hukum normatif dengan pendekatan peraturan perundang-undangan dan pendekatan analisis. Asas dan Norma Hukum Administrasi Negara dalam Pembuatan Instrumen Pemerintahan dalam tulisan ini menyimpulkan Penundaan Pemilihan Kepala Daerah Tahun 2020 dengan instrumen yuridis Undang - Undang Nomor 6 Tahun 2020 maupun Keputusan Komisi Pemilihan Umum Republik Indonesia Nomor: 179 /PL.02-Kpt/01/ KPU/III/2020 memenuhi unsur Pasal 5 Undang-Undang Nomor 30 Tahun 2014 tentang Administrasi Pemerintahan baik dari segi asas legalitas, asas perlindungan terhadap hak asasi manusia dan Asas-asas Umum Pemerintahan yang Baik (AUPB). Dalam pembahasan ada kesesuaian AUPB dengan Penundaan Pemilihan Kepala Daerah Tahun 2020 berdasarkan asas kepastian hukum dan asas kecermatan yang biasa digunakan dalam yurisprudensi ataupun doktrin.
\end{abstract}

Kata Kunci: pemilihan kepala daerah, pandemi Covid-19, Hukum Administrasi Negara

\begin{abstract}
General election is a method to elect people's representatives democratically. With the Covid-19 pandemic, the 2020 regional head elections were postponed. This is regulated in Undang-Undang Number 6 of 2020 and Decree of the General Election Commission of the Republic of Indonesia Number: 179/PL.02-Kpt/01/KPU/III/2020 concerning Postponement of Election Stages for Governors and Deputy Governors, Regents and Deputy Regents, and/or Mayor and Deputy Mayor of 2020 in Efforts to Prevent the Spread of Covid-19. This research uses normative legal research with a statutory approach and an analytical approach. The Principles and Norms of Administrative Law in Making Government Instruments in this paper concludes the Postponement of Regional Head Elections in 2020 with the juridical instrument Undang - Undang Number 6 of 2020 and the Decree of the General Election Commission of the Republic of Indonesia Number: 179/PL.02Kpt/01/KPU/III/2020 fulfills the elements of Article 5 of Law Number 30 of 2014 concerning Government Administration both in terms of legality principles, principles of protection of human rights and AUPB. In discussing the suitability of the AUPB with the Postponement of Regional Head Elections in 2020, it is based on the principles of legal certainty and the principles of accuracy commonly used in jurisprudence or doctrine.
\end{abstract}

Keywords: regional head election, Covid-19 pandemic, Administrative Law 


\section{A. Pendahuluan}

Pemilihan umum merupakan cara untuk memilih wakil-wakil rakyat secara demokratis. Di dalam praktik yang menjalankan kedaulatan rakyat adalah wakil rakyat yang duduk di lembaga perwakilan rakyat yang disebut parlemen. Para wakil rakyat itu bertindak atas nama rakyat dan wakil-wakil rakyat itulah yang menentukan corak dan cara bekerjanya pemerintahan serta tujuan apa yang hendak dicapai baik dalam jangka panjang maupun jangka waktu yang relatif pendek. Agar wakil-wakil rakyat benar-benar bertindak atas nama rakyat, wakil-wakil itu harus ditentukan sendiri oleh rakyat, yaitu melalui pemilihan umum (general election). ${ }^{1}$ Sila keempat Pancasila berbunyi Kerakyatan yang Dipimpin oleh Hikmat Kebijaksanaan dalam Permusyawaratan/ Perwakilan. Di dalam pengambilan keputusan lewat musyawarah mufakat ini yang menjadi prioritas utama adalah: "kualitas" itu sendiri, yaitu isi, bobot dari usulan yang diajukan. Pancasila sendiri merupakan etika politik. Etika adalah sebuah cabang filsafat yang berbicara mengenai nilai dan moral yang menentukan perilaku manusia dalam hidupnya. Manusia perlu berkelompok (zoon politicon) yang menampilkan insan berpikir sekaligus insan usaha (homo economicus). Sebagaimana disebutkan dalam Pembukaan Undang-Undang Dasar 1945 bahwa Indonesia adalah negara republik yang berkedaulatan rakyat tepatnya pada alinea keempat maka disimpulkan Indonesia adalah negara demokrasi.

Pada awal tahun 2020 badan kesehatan di bawah PBB sudah menyatakan wabah virus corona atau Covid-19 sebagai pandemi. Pandemi adalah kondisi dimana epidemi penyakit yang menyebar di wilayah yang luas mencakup lintas benua dalam skala global. Karena memenuhi 3 (tiga) kondisi yaitu virus dapat menyebabkan penyakit atau kematian, penularan virus orang ke orang yang berkelanjutan, dan bukti penyebaran di seluruh dunia maka suatu virus bisa dikatakan sebagai pandemi. Direktur Jenderal World Health Organization (WHO) Tedros Adanom Gebreyesus mengumumkan wabah virus corona sebagai pandemi dan dikhawatirkan tingkat penyebaran dan keparahan wabah virus corona bertambah karena kurangnya tindakan untuk memerangi virus. ${ }^{2}$ Berdasarkan data John Hopkins pada tanggal 11 Maret 2020 virus corona telah menginfeksi 121.564 orang di 118 negara. Virus tersebut dari Wuhan, Hubei, China. Di Indonesia virus corona mulai terdeteksi pada tanggal 2 Maret 2020. Di mana salah seorang warga negara Jepang yang positif mengidap corona di Malaysia ternyata sebelumnya memiliki riwayat perjalanan ke Indonesia. Tim dari Indonesia yang melakukan penelusuran telah menemukan dua orang yang memiliki riwayat kontak dengan pasien positif corona. Kejadian tersebut direspon sangat cepat. Presiden Joko Widodo mengeluarkan imbauan yaitu dengan kebijakan bekerja dari rumah, belajar dari rumah dan beribadah dari rumah pada konferensi pers di Istana Bogor Jawa Barat pada tanggal 15 Maret 2020. Beliau meminta untuk segera menanggapi status daerah siaga darurat atau tanggap darurat bencana non alam guna mengurangi persebaran virus korona. 
Salah satu yang dilakukan oleh Presiden Joko Widodo dengan adanya pandemi ini adalah penundaan pemilihan umum kepala daerah (pilkada) serentak tahun 2020 yang rencananya akan dilaksanakan pada tanggal 23 September 2020. Kemudian dikarenakan pandemi yang mengeluarkan kebijakan bekerja dari rumah, belajar dari rumah dan beribadah dari rumah maka menjadi tertundanya secara sementara pelaksanaan pilkada serentak tahun 2020. Hal ini diatur dalam Peraturan Pemerintah Pengganti Undang-Undang (Perpu) Nomor 2 Tahun 2020 tentang Perubahan Ketiga atas UndangUndang Nomor 1 Tahun 2015 tentang Penetapan Peraturan Pemerintah Pengganti Undang-Undang Nomor 1 Tahun 2014 tentang Pemilihan Gubernur, Bupati, dan Walikota Menjadi Undang-Undang. Lebih lanjut yang menjadi pertimbangan terbentuknya Perpu Nomor 2 Tahun 2020 adalah bahwa penyebaran Corona Virus Disease 2019 (COVID-19) yang telah dinyatakan sebagai pandemi oleh Organisasi Kesehatan Dunia (World Health Organization) yang terjadi di sebagian besar negara-negara di seluruh dunia, termasuk di Indonesia, telah menimbulkan banyak korban jiwa dan menunjukkan peningkatan dari waktu ke waktu serta telah ditetapkan sebagai bencana nasional. ${ }^{3}$ Dalam rangka penanggulangan penyebaran Corona Virus Disease 2019 (COVID-19) sebagai bencana nasional perlu diambil kebijakan dan langkahlangkah luar biasa baik di tingkat pusat maupun daerah termasuk perlunya dilakukan penundaan tahapan pelaksanaan pemilihan gubernur dan wakil gubernur, bupati dan wakil bupati, serta walikota dan wakil walikota serentak tahun 2020 agar pemilihan gubernur dan wakil gubernur, bupati dan wakil bupati, serta walikota dan wakil walikota tetap dapat berlangsung secara demokratis dan berkualitas serta untuk menjaga stabilitas politik dalam negeri.

Beberapa hal yang diubah dalam Perpu Nomor 2 Tahun 2020 adalah ketentuan Pasal 120 diubah sehingga berbunyi: ayat (1) Dalam hal pada sebagian wilayah Pemilihan, seluruh wilayah Pemilihan, sebagian besar daerah, atau seluruh daerah terjadi kerusuhan, gangguan keamanan, bencana alam, bencana non alam, atau gangguan lainnya yang mengakibatkan sebagian tahapan penyelenggaraan Pemilihan atau Pemilihan serentak tidak dapat dilaksanakan, dilakukan Pemilihan lanjutan atau Pemilihan serentak lanjutan. Kemudian Pasal 122 A ayat (1) berbunyi Pemilihan serentak lanjutan sebagaimana dimaksud dalam Pasal 120 dilaksanakan setelah penetapan penundaan tahapan pelaksanaan pemilihan serentak dengan Keputusan KPU diterbitkan. Kemudian dilanjutkan dengan Pasal $122 \mathrm{~A}$ ayat (2) yaitu penetapan penundaan tahapan pelaksanaan pemilihan serentak serta pelaksanaan pemilihan serentak lanjutan sebagaimana dimaksud pada ayat (1) dilakukan atas persetujuan bersama antara KPU, Pemerintah, dan Dewan Perwakilan Rakyat.

Undang-Undang Nomor 30 Tahun 2014 tentang Administrasi Pemerintahan (Lembaran Negara Tahun 2014 Nomor 292) merupakan salah satu peraturan perundangundangan yang menopang reformasi birokrasi

Peraturan Pemerintah Pengganti Undang-Undang Nomor 2 Tahun 2020 tentang Perubahan Ketiga atas UndangUndang Nomor 1 Tahun 2015 tentang Penetapan Peraturan Pemerintah Pengganti Undang-Undang Nomor 1 Tahun 2014 tentang Pemilihan Gubernur, Bupati, dan Walikota Menjadi Undang-Undang. 
dan penyelenggaraan kepemerintahan yang baik. Undang-Undang ini menjadi dasar hukum dalam penyelenggaraan pemerintahan, menjaga hubungan aparat pemerintahan dengan warga masyarakat, dan menciptakan birokrasi yang semakin baik, transparan, dan efisien. Pengaturan administrasi pemerintahan ke dalam suatu Undang-Undang bukanlah sesuatu yang baru. Administrasi Pemerintahan adalah tata laksana dalam pengambilan keputusan dan/ atau tindakan oleh badan dan/atau pejabat pemerintahan. Fungsi Pemerintahan adalah fungsi dalam melaksanakan Administrasi Pemerintahan yang meliputi fungsi pengaturan, pelayanan, pembangunan, pemberdayaan, dan pelindungan. Instrumen pemerintahan adalah alat-alat atau saranasarana yang digunakan oleh pemerintahan atau administrasi negara dalam melaksanakan tugas-tugasnya. Instrumen tersebut merupakan sarana yang disepakati oleh konstitusi sebagai alat yang legal digunakan oleh pemerintah dalam menjalankan tugas dan fungsinya. Intrumen yang digunakan tidak hanya di bidang hukum melainkan ada sarana prasarana, sarana ekonomi, sarana politik dan sarana kebudayaan. Pemerintah menggunakan berbagai instrumen yuridis dalam menjalankan kegiatan mengatur dan menjalankan urusan pemerintahan dan kemasyarakatan seperti peraturan perundangundangan, keputusan-keputusan, peraturan kebijakan, perijinan, instrumen hukum keperdataan dan sebagainya. Lebih lanjut dijelaskan dalam Undang-Undang Nomor 30 Tahun $2014^{4}$ Pasal 5 menyebutkan bahwa penyelenggaraan administrasi pemerintahan berdasarkan asas legalitas, asas perlindungan terhadap hak asasi manusia dan Asas-asas Umum Pemerintahan yang Baik (AUPB).

Oleh karena itu, Penundaan Pemilihan Kepala Daerah pada Masa Pandemi Covid-19 dalam Perspektif Hukum Administrasi Negara menjadi kajian yang cukup menarik. Dalam Penundaan Pemilihan Kepala Daerah Tahun 2020 terdapat 2 instrumen pemerintahan yang penting, yaitu Perpu Nomor 2 Tahun 2020 dan Keputusan Komisi Pemilihan Umum Republik Indonesia Nomor: 179/PL.02-Kpt/01 /KPU/III/2020 tentang Penundaan Tahapan Pemilihan Gubernur Dan Wakil Gubernur, Bupati Dan Wakil Bupati, Dan/Atau Walikota Dan Wakil Walikota Tahun 2020 Dalam Upaya Pencegahan Penyebaran Covid-19. Dalam kajian Hukum Administrasi Negara Perpu Nomor 2 Tahun 2020 merupakan salah satu instrumen pemerintahan yang termasuk dalam peraturan perundang-undangan sesuai dengan Undang-Undang Nomor 12 Tahun 2011 tentang Pembentukan Peraturan Perundangundangan sebagaimana telah diubah dengan Undang-Undang Nomor 15 Tahun 2019. Pasal 7 ayat (1) Undang-Undang Nomor 12 Tahun 2011 menentukan bahwa jenis dan hierarki Peraturan Perundang-undangan terdiri atas: a) Undang-Undang Dasar Negara Republik Indonesia Tahun 1945; b) Ketetapan Majelis Permusyawaratan Rakyat; c) UndangUndang/ Peraturan Pemerintah Pengganti Undang-Undang; d) Peraturan Pemerintah; e) Peraturan Presiden; f) Peraturan Daerah Provinsi; dan g) Peraturan Daerah Kabupaten/ Kota. ${ }^{5}$ Kemudian pada tanggal 11 Agustus 2020 
Perpu Nomor 2 Tahun 2020 ini ditetapkan menjadi menjadi Undang - Undang Nomor 6 Tahun 2020 tentang Penetapan Peraturan Pemerintah Pengganti Undang-Undang Nomor 2 Tahun 2020 Tentang Perubahan Ketiga Atas undang-Undang Nomor 1 Tahun 2015 Tentang penetapan Peraturan Pemerintah Pengganti Undang-Undang Nomor 1 Tahun 2014 Tentang Pemilihan Gubernur, Bupati, Dan Walikota Menjadi Undang-Undang menjadi UndangUndang. ${ }^{6}$

Sedangkan Keputusan Komisi Pemilihan Umum Republik Indonesia Nomor: 179/PL.02Kpt/01/KPU/II/2020 termasuk Keputusan Tata Usaha Negara atau beschikking. Karena sesuai dengan Pasal 1 angka 3 Undang-Undang Nomor 5 Tahun 1986 tentang Peradilan Tata Usaha Negara sebagaimana telah diubah dengan Undang-Undang Nomor Nomor 9 Tahun 2004 dan Undang - Undang Nomor 51 Tahun 2009, keputusan didefinisikan sebagai suatu penetapan tertulis yang dikeluarkan oleh Badan atau Pejabat Tata Usaha Negara yang berdasarkan peraturan peraturan perundang-undangan yang berlaku, yang bersifat konkret, individual dan final, yang menimbulkan akibat hukum bagi seseorang atau badan hukum perdata. ${ }^{7}$

Hal ini berbeda dengan tulisan di jurnal sebelumnya yaitu tentang Asas dan Norma Hukum Administrasi Negara dalam Pembuatan Instrumen Pemerintahan yang membahas bahwa Peraturan adalah hukum in abstracto atau general norm yang sifatnya mengikat umum (berlaku umum) dan tugasnya adalah mengatur hal-hal yang bersifat umum (general). Berdasarkan penjelasan Pasal 1 angka 2 Undang-Undang Nomor 5 Tahun 1986 tentang Peradilan Tata Usaha Negara yang dimaksud dengan peraturan perundangundangan adalah semua peraturan yang bersifat mengikat secara umum yang dikeluarkan oleh Badan Perwakilan Rakyat bersama pemerintah baik di tingkat pusat maupun daerah, serta semua keputusan badan atau pejabat tata usaha negara, baik di tingkat pusat, maupun di daerah, yang juga mengikat umum.

Sementara Peraturan kebijakan hanya berfungsi sebagai bagian dari operasional penyelenggaraan tugas-tugas pemerintahan, karenanya tidak dapat mengubah ataupun menyimpangi peraturan perundangundangan. Peraturan ini adalah semacam hukum bayangan dari undang-undang atau hukum. Oleh karena itu, peraturan ini disebut pula dengan istilah pseudo wetgeving (perundang-undangan semu) atau spigelsrecht (hukum bayangan/cermin). Secara praktis kewenangan diskresioner administrasi negara yang kemudian melahirkan peraturan kebijakan, mengandung dua aspek pokok; Pertama, kebebasan menafsirkan mengenai ruang lingkup wewenang yang dirumuskan dalam peraturan dasar wewenangnya. Aspek pertama ini lazim dikenal dengan kebebasan menilai yang bersifat objektif. Kedua, kebebasan untuk menentukan sendiri dengan cara bagaimana dan kapan wewenang yang dimilki administrasi negara itu dilaksanakan.

Berkenaan dengan Keputusan (beschikking), meskipun diasumsikan bahwa setiap keputusan yang telah dikeluarkan dianggap sah oleh hukum, akan tetapi di

Undang - Undang Nomor 6 Tahun 2020.

Undang-Undang Nomor 5 Tahun 1986 tentang Peradilan Tata Usaha Negara sebagaimana telah diubah dengan Undang-Undang Nomor 9 Tahun 2004 dan Undang-Undang Nomor 51 Tahun 2009. 
dalam praktik hampir semua surat keputusan, khususnya dalam praktik administrasi negara di Indonesia, terdapat klausula pengaman (veiligheidsclausule) yang pada umumnya berbunyi: "Apabila di kemudian hari terdapat kekeliruan atau kekurangan, maka surat keputusan ini akan ditinjau kembali". Rumusan seperti itu di satu sisi bertentangan dengan asas kepastian hukum dan di sisi lain bertentangan dengan asas praduga rechtmatig. Dengan kata lain, klausul pengaman itu merupakan sesuatu hal yang keliru, tidak bermanfaat dan mubazir, sebab dapat menggoyahkan sendi-sendi kepastian hukum. Karena rumusan seperti ini, di satu sisi bertentangan dengan asas kepastian hukum dan di sisi lain bertentangan dengan asas praduga rechtmatig. ${ }^{8}$

Selain itu, dari jurnal yang membahas Undang-Undang Nomor 30 Tahun 2014 dapat disimpulkan bahwa banyak sekali perdebatan mengenai substansi dari undang undang ini. Seperti dalam jurnal yang berjudul Kompetensi Absolut Pengadilan Tata Usaha Negara Dalam Konteks Undang-Undang Nomor 30 Tahun 2014 tentang Administrasi Pemerintahan terdapat beberapa pembahasan. Misalnya, dalam Pasal 10 ayat (1) Undang-Undang tentang Administrasi Pemerintahan memuat rincian AUPB. Namun, dalam penjelasan Pasal 53 ayat (2) sub b Undang-Undang Nomor 9 Tahun 2004 dimuat hal yang berbeda. Dengan demikian terdapat adanya antinomi. Pengujian terhadap keputusan
Administrasi berdasarkan Undang-Undang tentang Administrasi Pemerintahan pada prinsipnya sama dengan Keputusan dalam Undang-Undang tentang Peradilan Tata Usaha Negara. Hakim menguji berdasarkan peraturan perundang-undangan dan AUPB. Adanya perbedaan muatan AUPB dalam UU tentang Peradilan Tata Usaha Negara dan Undang-Undang tentang Administrasi Pemerintahan dalam praktik di PTUN tidak menjadi masalah. Oleh karena, selain AUPB yang dimuat dalam kedua undang-undang tersebut, hakim dapat menguji keputusan atau tindakan berdasarkan AUPB di luar yang dimuat dalam UU. Hakikat AUPB sebetulnya tidak tertulis. Rincian AUPB yang dimuat dalam Pasal 10 Undang-Undang tentang Administrasi Pemerintahan menyebabkan bukan asas (tidak tertulis) lagi melainkan sudah menjadi norma dalam undang-undang. AUPB harus asas hukum. Asas kemanfaatan dan asas kepentingan umum bukan asas hukum. Asas kemanfaatan mengandung arti efektifitas dan efisien. Efektifitas mengandung kemanfaatan sedangkan efisien mengandung nilai ekonomis. ${ }^{9}$

Penulisan dengan judul Penundaan Pemilihan Kepala Daerah pada Masa Pandemi Covid-19 dalam PerspektifHukum Administrasi Negara ini dibatasi dengan rumusan masalah sebagai berikut: 1) Bagaimana Penundaan Pemilihan Kepala Daerah pada masa pandemi Covid-19 dengan menggunakan instrumen yuridis Undang - Undang Nomor 6 Tahun 
2020 dikaji dengan Pasal 5 Undang-Undang Nomor 30 Tahun 2014 tentang Administrasi Pemerintahan berdasarkan asas legalitas, asas perlindungan terhadap hak asasi manusia dan AUPB?; 2) Bagaimana Penundaan Pemilihan Kepala Daerah pada masa pandemi Covid-19 dengan menggunakan instrumen yuridis Keputusan Komisi Pemilihan Umum Republik Indonesia Nomor: 179/PL.02-Kpt/01/ KPU/ III/2020 dikaji dengan Pasal 5 Undang-Undang Nomor 30 Tahun 2014 tentang Administrasi Pemerintahan berdasarkan asas legalitas, asas perlindungan terhadap hak asasi manusia dan AUPB?

\section{B. Metode Penelitian}

Metode penelitian dalam jurnal ini adalah penelitian hukum normatif yang meletakkan hukum sebagai sebuah bangunan sistem norma. Dalam penelitian hukum normatif ini menggunakan pendekatan perundang-perundangan (Statute Approach)..$^{10}$ Hal ini dimaksudkan bahwa penelitian ini dilakukan dengan menggunakan peraturan perundang-undangan sebagai dasar awal untuk menganalisis masalah yang dirumuskan. Peraturan perundangundangan yang dimaksud yaitu UndangUndang Nomor 30 Tahun 2014 tentang Administrasi Pemerintahan sebagai bentuk aturan dalam kajian Hukum Administrasi Negara, khususnya Pasal 5 dan masalah yang dianalisis adalah Penundaan Pemilihan Kepala Daerah pada masa pandemi Covid-19 dengan menggunakan instrumen hukum Undang Undang Nomor 6 Tahun 2020 dan Keputusan Komisi Pemilihan Umum Republik Indonesia Nomor: 179/PL.02-Kpt/01/KPU/III/2020.
Tulisan ini juga menggunakan pendekatan analisis yaitu menganalisis ketentuan Pasal 5 Undang-Undang Nomor 30 Tahun 2014 yang menentukan bahwa penyelenggaraan administrasi pemerintahan berdasarkan asas perlindungan terhadap hak asasi manusia. Selain itu, juga dianalisis jenis hak asasi manusia seperti apa saja yang bisa dilindungi dengan adanya kebijakan Penundaan Pemilihan Kepala Daerah Tahun 2020.

\section{Pembahasan}

1. Penundaan Pemilihan Kepala Daerah Pada Masa Pandemi Covid-19 dengan menggunakan instrumen yuridis Undang - Undang Nomor 6 Tahun 2020 dikaji dengan Pasal 5 UndangUndang Nomor 30 Tahun 2014 tentang Administrasi Pemerintahan berdasarkan asas legalitas, asas perlindungan terhadap hak asasi manusia dan AUPB

Sejak dianutnya konsepsi welfare state (Philipus M Hadjon, dkk, 2008) yang menempatkan pemerintah sebagai pihak yang bertanggung jawab terhadap kesejahteraan umum warga negara dan untuk mewujudkan kesejahteraan inipemerintah diberi wewenang untuk campur tangan dalam segala lapangan kehidupan masyarakat. Dalam campur tangan ini tidak hanya berdasarkan pada peraturan perundang-undangan saja, tetapi dalam keadaan tertentu berdasarkan inisiatif sendiri melalui freies Ermessen atau diskresionare. Undang-Undang Nomor 30 Tahun 2014 tentang Administrasi Pemerintahan merupakan salah satu peraturan yang menopang reformasi birokrasi dan penyelenggaraan pemerintahan yang baik. Selain menjadi landasan hukum

10 Johnny Ibrahim, Teori dan Metode Penelitian Hukum Normatif, (Malang: Boymedia Publishing, 2006 ), hlm 303. 
bagi penyelenggaraan pemerintahan, undangundang ini juga menjaga hubungan antara aparat pemerintahan dengan masyarakat dan meningkatkan kualitas pelayanan pemerintah sehingga tercipta birokrasi yang baik, transparan dan efisien.

Pengaturan tentang Administrasi Pemerintahan ke dalam suatu undangundang bukanlah sesuatu hal yang baru. Di Eropa dan Amerika terdapat beberapa negara sudah memiliki undang-undang tersebut seperti Undang-Undang Prosedur Administrasi Negara Republik Federal Jerman (Verwaltungsverfahrensgesetz des Bundes); di Spanyol terdapat Azcarate Law sejak tahun 1889; Austria memiliki Allgemeines Verwaltungsverfahrensgesetz sejak tahun 1921; Italia memiliki Administrative Code tahun 1990; Belanda sudah memiliki Administratief Wet Bestuursrecht dan di Amerika Serikat sendiri terdapat Administrative Procedure Act tahun $1946 .{ }^{11}$

Pengertian Administrasi Pemerintahan dalam Pasal 2 Undang-Undang Nomor 30 Tahun 2014 adalah salah satu dasar hukum bagi Badan dan/atau Pejabat Pemerintahan, Warga Masyarakat, dan pihak-pihak lain yang terkait dengan Administrasi Pemerintahan dalam upaya meningkatkan kualitas penyelenggaraan pemerintahan. Pada Pasal 5 Undang-Undang Nomor 30 Tahun 2014 disebutkan bahwa Penyelenggaraan administrasi pemerintahan berdasarkan 3 (tiga) hal yaitu asas legalitas, asas perlindungan terhadap hak asasi manusia dan Asas-asas Umum Pemerintahan yang Baik (AUPB).

Penundaan pemilihan Kepala Daerah Tahun 2020 pertama diatur dalam Perpu Nomor 2 Tahun 2020 dilakukan dalam rangka penanggulangan penyebaran Corona Virus Disease 2019 (COVID-19) sebagai bencana nasional perlu diambil kebijakan dan langkahlangkah luar biasa baik di tingkat pusat maupun daerah termasuk perlunya dilakukan penundaan tahapan pelaksanaan pemilihan gubernur dan wakil gubernur, bupati dan wakil bupati, serta walikota dan wakil walikota serentak tahun 2020 agar pemilihan gubernur dan wakil gubernur, bupati dan wakil bupati, serta walikota dan wakil walikota tetap dapat berlangsung secara demokratis dan berkualitas serta untuk menjaga stabilitas politik dalam negeri. ${ }^{12}$

Kemudian pada tanggal 11 Agustus 2020 Perpu Nomor 2 Tahun 2020 ini ditetapkan menjadi menjadi Undang - Undang Nomor 6 Tahun 2020 tentang Penetapan Peraturan Pemerintah Pengganti Undang-Undang Nomor 2 Tahun 2020 Tentang Perubahan Ketiga Atas undang-Undang Nomor 1 Tahun 2015 Tentang penetapan Peraturan Pemerintah Pengganti Undang-Undang Nomor 1 Tahun 2014 Tentang Pemilihan Gubernur, Bupati, Dan Walikota Menjadi Undang-Undang menjadi UndangUndang. ${ }^{13}$

11 Muhammad Yasin et al, Anotasi Undang-Undang Nomor 30 Tahun 2014 tentang Administrasi Pemerintahan, (Universitas Indonesia - Center for Study of Governance and Administrative Reform (UI-CSGAR), 2017 ), hlm 2 -3.

12 Perpu Nomor 2 Tahun 2020 tentang Perubahan Ketiga atas Undang-Undang Nomor 1 Tahun 2015 tentang Penetapan Peraturan Pemerintah Pengganti Undang-Undang Nomor 1 Tahun 2014 tentang Pemilihan Gubernur, Bupati, dan Walikota Menjadi Undang-Undang.

13 Undang - Undang Nomor 6 Tahun 20202020 tentang Penetapan Peraturan Pemerintah Pengganti UndangUndang Nomor 2 Tahun 2020 Tentang Perubahan Ketiga Atas undang-Undang Nomor 1 Tahun 2015 Tentang penetapan Peraturan Pemerintah Pengganti Undang-Undang Nomor 1 Tahun 2014 Tentang Pemilihan Gubernur, Bupati, Dan Walikota Menjadi Undang-Undang menjadi Undang-Undang. 
Guna mengetahui kualifikasi sifat keumuman (algemeenheid) dan kekonkretan (concreetheid) norma Hukum Administrasi Negara, perlu diperhatikan mengenai objek yang dikenai norma hukum (adressaat) dan bentuk normanya. Dengan kata lain, kepada siapa norma hukum itu ditujukan apakah untuk umum atau tertentu. Empat macam sifat norma hukum, yaitu:

1. Norma umum abstrak misalnya undangundang.

2. Norma individual konkret misalnya keputusan tata usaha negara.

3. Norma umum konkret misalnya rambu rambu lalu lintas yang dipasang di tempat tertentu (rambu itu berlaku bagi semua pemakai jalan, namun hanya berlaku untuk tempat itu).

4. Norma individual abstrak misalnya izin gangguan. ${ }^{14}$

Kualifikasi norma hukum yang hampir sama dikemukakan pula oleh H.D van Wijk/ Willem Konijnenbelt, yakni sebagai berikut:

1. Algemeen-abstract: de algemene regeling, bijvoorbeeld het Reglement verkeersregels en verkeerstekens 1990 (een algemene maatregel van bestuur), een bouwverordening; (umum-abstrak: peraturan umum, contohnya peraturan perundang-undangan lalu lintas jalan 1990 (suatu peraturan pemerintah), peraturan bangunan).

2. Algemeen-concreet: besluit tothet instellen van een parkeer verbod voor een bepaald straatgedeelte, onbewoonbaarverklaring van een pand; (umum-konkret: keputusan tentang larangan parkir pada jalan tertentu, pernyataan yang tidak dapat didiaminya suatu rumah (larangan mendirikan rumah pada wilayah tertentu).

3. Individueel-abstract: de vergunning met permanente; abstracte werking waaraan voorschriften zijn verbonden, bijvoorbeeld de vergunning krachtens de Wet milieubeheer; (individual-abstrak: izin yang disertai syarat-syarat yang bersifat mengatur dan abstrak serta berlaku secara permanen, contohnya izin berdasarkan undang-undang pengelolaan lingkungan.

4. Individueel-concreet: belastingaanslag, toekenning subsidie voor een eenmalige activiteit, besluit tot het toepassen van bestuursdwang; (individual-konkret: surat keputusan pajak, pemberian subsidi untuk suatu kegiatan, keputusan mengenai pelaksanaan paksaan pemerintahan). ${ }^{15}$

Jika dianalisis maka Undang - Undang Nomor 6 Tahun 2020 sebagai instrumen yuridis penundaan pemilihan kepala daerah serentak tahun 2020 termasuk ke dalam salah satu jenis peraturan perundang-perundangan yaitu Undang - Undang berdasarkan Pasal 7 ayat (1) Undang-Undang Nomor 12 Tahun 2011 sebagaimana telah diubah dengan UndangUndang Nomor 15 Tahun 2019. Pasal 1 angka 3 Undang-Undang Nomor 12 Tahun 2011 sebagaimana telah diubah dengan UndangUndang Nomor 15 Tahun 2019 menentukan bahwa Undang-Undang adalah Peraturan Perundang-undangan yang dibentuk oleh Dewan Perwakilan Rakyat dengan persetujuan bersama Presiden. Kemudian diatur juga dalam Pasal 7 ayat (1) Undang-Undang Nomor 12 Tahun 2011 tentang Pembentukan

14 Philipus M.Hadjon, et al., Pengantar Hukum Administrasi Indonesia (Yogyakarta: Gadjah Mada University Press, 1993).

15 H.D Van Wijk en Willem Konijnenbelt. Hoofdstukken van Administratief Recht. (s'Gravenhage: Vuga, 1995). 
Peraturan Perundang-Undangan sebagaimana telah diubah dengan Undang-Undang Nomor 15 Tahun 2019 yang menentukan bahwa Jenis dan hierarki Peraturan Perundang-undangan terdiri atas: a) Undang-Undang Dasar Negara Republik Indonesia Tahun 1945; b) Ketetapan Majelis Permusyawaratan Rakyat; c) UndangUndang/Peraturan Pemerintah Pengganti Undang-Undang; d) Peraturan Pemerintah; e) Peraturan Presiden; f) Peraturan Daerah Provinsi; dan g) Peraturan Daerah Kabupaten / Kota.

Pasal 1 angka 2 Undang-Undang Nomor 12 Tahun 2011 sebagaimana telah diubah dengan Undang-Undang Nomor 15 tahun 2019 menentukan bahwa Peraturan Perundangundangan adalah peraturan tertulis yang memuat norma hukum yang mengikat secara umum dan dibentuk atau ditetapkan oleh lembaga negara atau pejabat yang berwenang melalui prosedur yang ditetapkan dalam Peraturan Perundang-undangan. Kemudian dijelaskan juga pada Pasal 1 angka 2 UndangUndang Nomor 5 Tahun 1986 sebagaimana telah diubah dengan Undang-Undang Nomor Nomor 9 Tahun 2004 dan Undang-Undang Nomor 51 Tahun 2009 tentang Peradilan Tata Usaha Negara, peraturan perundangundangan adalah semua peraturan yang bersifat mengikat secara umum yang dikeluarkan oleh Badan Perwakilan Rakyat bersama pemerintah baik di tingkat pusat maupun di tingkat daerah, serta semua Keputusan badan atau pejabat tata usaha negara, baik di tingkat pusat maupun daerah, yang juga mengikat umum.

Selanjutnya penundaan pemilihan kepala daerah tahun 2020 dengan menggunakan instrumen yuridis Undang - Undang Nomor 6 Tahun 2020 sendiri sebagai administrasi pemerintahan telah memenuhi unsur asas perlindungan terhadap hak asasi manusia yaitu bahwa penyelenggaraan Administrasi Pemerintahan, Badan dan/atau Pejabat Pemerintahan tidak boleh melanggar hak-hak dasar Warga Masyarakat sebagaimana dijamin dalam Undang-Undang Dasar Negara Republik Indonesia Tahun 1945. Secara konstitusional hak asasi manusia diatur dalam Pasal 28 A 28 J Undang-Undang Dasar Negara Republik Indonesia Tahun 1945. Seperti pada Pasal 28 A yang menyebutkan setiap orang berhak untuk hidup serta berhak mempertahankan hidup dan kehidupannya. Penundaan pemilihan kepala daerah tahun 2020 adalah salah satu upaya pemerintah untuk mengurangi risiko kematian yang disebabkan oleh penularan virus corona yang dinyatakan WHO sebagai pandemi. Dimana pandemi adalah kondisi yaitu virus dapat menyebabkan penyakit atau kematian, penularan virus orang ke orang yang berkelanjutan, dan bukti penyebaran di seluruh dunia. Kemudian Pasal $28 \mathrm{H}$ ayat (1) menyebutkan setiap orang berhak hidup sejahtera lahir dan batin, bertempat tinggal dan mendapatkan lingkungan yang baik dan sehat serta berhak memperoleh pelayanan kesehatan. Seperti diketahui penundaan pemilihan kepala daerah tahun 2020 terkait dengan mekanisme kerja yang dilakukan dalam rangka persiapan pemilihan kepala daerah tersebut dikarenakan wabah Covid-19 maka setiap pelaksanaan harus dilakukan dengan menggunakan protokol kesehatan agar mencegah penularan virus tersebut.

Selanjutnya Pasal $28 \mathrm{~J}$ ayat menentukan bahwa Dalam menjalankan hak dan kebebasannya, setiap orang wajib tunduk kepada pembatasan yang ditetapkan dengan undang-undang dengan maksud 
semata-mata untuk menjamin pengakuan serta penghormatan atas hak dan kebebasan orang lain dan untuk memenuhi tuntutan yang adil sesuai dengan pertimbangan moral, nilai-nilai agama, keamanan, dan ketertiban umum dalam suatu masyarakat demokratis. Penundaan Pemilihan Kepala Daerah Tahun 2020 ini sudah benar diatur dalam berbagai peraturan hal ini tidak lain untuk mencegah penularan virus Covid-19 yang menjadi pandemi.

Dinormakan dan diperincinya Asas-Asas Umum Pemerintahan Yang Baik (AUPB) di dalam Pasal 10 ayat (1) Undang-Undang Nomor 30 Tahun 2014 tentang Administrasi Pemerintahan telah membuat AUPB itu sendiri tidak sesuai dengan hakikat AUPB yang merupakan hukum tidak tertulis dan bersifat elastis mengikuti perkembangan praktik pemerintahan dan peradilan tata usaha negara. Ketika asas sudah dinormakan maka ia menjadi undang-undang tidak dapat lagi disebut sebagai asas. ${ }^{15}$ Kajian normatif yang dilakukan terhadap AUPB adalah melihat kesesuaian dari instrumen yuridis tentang penundaan pemilihan kepala daerah tahun 2020 dengan penerapan Pasal 5 UndangUndang Nomor 30 Tahun 2014 khususnya mengenai AUPB hanya menganalisis 2 (dua) asas yaitu asas kepastian hukum dan asas kecermatan. Meskipun di dalam Pasal 10 tentang AUPB berisi 8 asas akan tetapi 2 (dua) asas tadi sering digunakan dalam yurisprudensi maupun doktrin sehingga tidak bertentangan dengan konsep dasar Hukum Administrasi yaitu ciri umum AUPB adalah tidak tertulis dan merupakan kesadaran hukum umum yang hidup.

Selain sudah memenuhi unsur asas legalitas dan asas perlindungan terhadap hak asasi manusia, penundaan Pemilihan Kepala Daerah Tahun 2020 dengan menggunakan instrumen yuridis Undang - Undang Nomor 6 Tahun 2020 juga sudah sesuai dengan AUPB. Yang dimaksud dengan AUPB dalam Undang-Undang Nomor 30 Tahun 2014 adalah sesuai dengan Pasal 10 ayat (1) yaitu asas kepastian hukum, asas kemanfaatan, asas ketidakberpihakan, asas kecermatan, asas tidak menyalahgunakan kewenangan, asas keterbukaan, asas kepentingan umum dan asas pelayanan yang baik. Kemudian masing-masing asas tersebut dijelaskan lebih lanjut dalam penjelasan atas Undang-Undang Nomor 30 Tahun 2014 tentang Administrasi Pemerintahan. Sebagaimana telah dijelaskan di atas, diaturnya secara rinci AUPB dalam undang-undang ini justru tidak sesuai dengan teori hukum administrasi. Oleh karena itu, dalam tulisan ini dibuat analisis AUPB yang biasa digunakan baik dalam doktrin maupun yurisprudensi, yaitu asas kepastian hukum dan asas kecermatan.

Pengertian asas kepastian hukum adalah asas dalam negara hukum yang mengutamakan landasan ketentuan peraturan perundangundangan, kepatutan, keajegan, dan keadilan dalam setiap kebijakan penyelenggaraan pemerintahan. ${ }^{16}$ Dengan demikian, dapat dikatakan bahwa Penundaan Pemilihan Kepala Daerah Tahun 2020 dengan menggunakan instrumen yuridis Undang - Undang Nomor

\footnotetext{
15 Philipus M Hadjon, Peradilan Tata Usaha Negara Dalam Konteks Undang-Undang Nomor 30 Tahun 2014 tentang Administrasi Pemerintahan, http://114.129.22.229:4070/ index.php/jurnalhukumperadilan/article/view/74, Jurnal Hukum dan Peradilan, Volume 4 Nomor 1 tahun 2015, (diakses tanggal 25 Agustus 2020).

16 Undang-Undang Nomor 30 Tahun 2014 tentang Administrasi Pemerintahan.
} 
6 Tahun 2020 adalah berlandaskan pada asas kepastian hukum melalui salah satu jenis peraturan perundang-undangan yaitu peraturan pemerintah pengganti undangundang.

Kemudian asas kecermatan, yaitu asas yang mengandung arti bahwa suatu Keputusan dan/atau Tindakan harus didasarkan pada informasi dan dokumen yang lengkap untuk mendukung legalitas penetapan dan/ atau pelaksanaan Keputusan dan/atau Tindakan sehingga Keputusan dan/ atau Tindakan yang bersangkutan dipersiapkan dengan cermat sebelum Keputusan dan/ atau Tindakan tersebut ditetapkan dan/atau dilakukan. ${ }^{17}$ Penundaan Pemilihan Kepala Daerah Tahun 2020 dengan menggunakan instrumen yuridis Undang - Undang Nomor 6 Tahun 2020 dibuat dengan dukungan data yang akurat secara saintifik baik dari WHO maupun pemerintah yang kemudian disusul dengan pembentukan Gugus Tugas Percepatan Penanganan Covid-19.

2. Penundaan Pemilihan Kepala Daerah pada masa pandemi Covid-19 dengan menggunakan instrumen yuridis Keputusan Komisi Pemilihan Umum Republik Indonesia Nomor: 179/PL.02-Kpt/ 01/KPU/III/2020 dikaji dengan Pasal 5 UndangUndang Nomor 30 Tahun 2014 tentang Administrasi Pemerintahan berdasarkan asas legalitas, asas perlindungan terhadap hak asasi manusia dan AUPB

Penundaan pemilihan kepala daerah selain berdasarkan Undang - Undang Nomor 6 Tahun 2020 juga berdasarkan Keputusan Komisi Pemilihan Umum Republik Indonesia
Nomor: $\quad$ 179/PL.02-Kpt/01/KPU/III/2020. Dalam kajian Hukum Administrasi Negara, Keputusan Komisi Pemilihan Umum Republik Indonesia Nomor: 179/PL.02-Kpt/01/KPU/ III/2020 tergolong keputusan tata usaha negara karena memenuhi unsur: 1) penetapan tertulis; 2) dikeluarkan oleh Badan/Pejabat TUN; 3) berdasarkan peraturan perundangundangan yang berlaku; 4) bersifat konkret, individual dan final; 5) menimbulkan akibat hukum; 6) seseorang atau badan hukum perdata.

Berikut ini penjelasan satu persatu mengenai unsur-unsur Keputusan TUN di atas. Keputusan Komisi Pemilihan Umum Republik Indonesia Nomor: 179/ PL.02-Kpt/01/KPU/ III/2020 bentuknya adalah penetapan tertulis, dikeluarkan oleh Ketua Komisi Pemilihan Umum Republik Indonesia sebagai Pejabat Tata Usaha Negara. Kemudian, Keputusan Tata Usaha Negara ini dibuat berdasarkan peraturan perundangan-undangan yang berlaku yaitu Undang - Undang Nomor 6 Tahun 2020. Selanjutnya, bersifat konkret, individual dan final yaitu tentang Penundaan Tahapan Pemilihan Gubernur Dan Wakil Gubernur, Bupati Dan Wakil Bupati, dan/ atau Wali Kota Dan Wakil Wali Kota tahun 2020 Dalam Upaya Pencegahan Penyebaran Covid-19. Unsur yang terakhir, Keputusan TUN ini menimbulkan akibat hukum tertentu bagi yang dituju dalam keputusan tata usaha negara tersebut dan merupakan wujud dari tindakan hukum publik sepihak dari organ pemerintahan ditujukan kepada subjek hukum yang tertulis di dalamnya. Oleh karena itu, dapat dikatakan bahwa penundaan pemilihan Kepala Daerah Tahun 2020 dengan menggunakan instrumen yuridis

17 Undang-Undang Nomor 30 Tahun 2014 tentang Administrasi Pemerintahan. 
Keputusan Komisi Pemilihan Umum Republik Indonesia Nomor: 179/PL.02-Kpt/0/KPU/ III/2020 berdasarkan asas legalitas. Hal ini mencerminkan bahwa penundaan pemilihan Kepala Daerah Tahun 2020 berdasarkan asas legalitas dimana terdapat aturan yang mengatur, baik berdasarkan pada peraturan perundang-undangan maupun dengan Keputusan Tata Usaha Negara.

Selain itu, penundaan pemilihan Kepala Daerah Tahun 2020 dengan menggunakan instrumen yuridis Keputusan Komisi Pemilihan Umum Republik Indonesia Nomor: 179/ PL.02-Kpt/01/KPU/III/2020 berdasarkan asas perlindungan terhadap hak asasi manusia. Hal ini dibuktikan dengan masa kerja panitia pemungutan suara yang sudah dilantik harus ditunda, yang berarti sesuai dengan implementasi pasal $28 \mathrm{G}$ ayat (1) UndangUndang Dasar 1945 yang menentukan bahwa setiap orang berhak hidup sejahtera lahir dan batin, bertempat tinggal, dan mendapatkan lingkungan hidup yang baik dan sehat serta berhak memperoleh pelayanan kesehatan.

Selain berdasarkan asas legalitas dan asas perlindungan terhadap hak asasi manusia, penundaan pemilihan Kepala Daerah Tahun 2020 dengan menggunakan instrumen yuridis Keputusan Komisi Pemilihan Umum Republik Indonesia Nomor: 179/ PL.02-Kpt/01/KPU/ III/2020 juga berdasarkan AUPB yaitu asas kecermatan dan asas kepastian hukum. Karena pengertian asas kepastian hukum adalah asas dalam negara hukum yang mengutamakan landasan ketentuan peraturan perundangundangan, kepatutan, keajegan, dan keadilan dalam setiap kebijakan penyelenggaraan pemerintahan. Dengan demikian, penundaan pemilihan Kepala Daerah Tahun 2020 dengan menggunakan instrumen yuridis Keputusan
Komisi Pemilihan Umum Republik Indonesia Nomor: 179/PL.02-Kpt/01/KPU/III/2020 adalah sudah tepat karena berlandaskan pada asas kepastian hukum. Selain itu, asas kecermatan yang mengandung arti bahwa suatu Keputusan dan/atau Tindakan harus didasarkan pada informasi dan dokumen yang lengkap untukmendukung legalitas penetapan dan/atau pelaksanaan Keputusan dan/atau Tindakan sehingga Keputusan dan/atau Tindakan yang bersangkutan dipersiapkan dengan cermat sebelum Keputusan dan/ atau Tindakan tersebut ditetapkan dan/atau dilakukan. Penundaan Pemilihan Kepala Daerah Tahun 2020 dengan menggunakan instrumen yuridis Keputusan Komisi Pemilihan Umum Republik Indonesia Nomor: 17 /PL.02-Kpt/01/KPU/III/2020 dibuat dengan dukungan data akurat secara saintifik baik dari WHO maupun pemerintah yang kemudian disusul dengan pembentukan Gugus Tugas Percepatan Penanganan Covid-19. Selain itu, pertimbangan dikeluarkannya Keputusan Komisi Pemilihan Umum Republik Indonesia Nomor: 17 /PL.02-Kpt/01/KPU/III/2020 juga dikaitkan dengan: 1) Keputusan Kepala Badan Nasional Penanggulangan Bencana Nomor 13.A Tahun 2020 tentang Perpanjangan Status Keadaan Tertentu Darurat Bencana Wabah Penyakit Akibat Virus Corona di Indonesia; dan 2) Surat Badan Pengawas Pemilihan Umum Republik Indonesia Nomor S-0235/K. BAWASLU/PM.00.00/3/2020 tanggal 16 Maret 2020 perihal Antisipasi Dampak Virus Covid-19 terhadap Penyelenggaraan Tahapan Pemilihan Gubernur, Bupati, dan Walikota Tahun 2020. 


\section{Penutup}

Penundaan pemilihan Kepala Daerah pada masa pandemi Covid-19 di tahun 2020 dengan menggunakan instrumen yuridis Undang - Undang Nomor 6 Tahun 2020 telah memenuhi unsur Pasal 5 Undang-Undang Nomor 30 Tahun 2014 tentang Administrasi Pemerintahan, baik dari segi asas legalitas, asas perlindungan terhadap hak asasi manusia maupun AUPB.

Penundaan Pemilihan Kepala Daerah pada masa pandemi Covid-19 di tahun 2020 dengan menggunakan instrumen yuridis Keputusan Komisi Pemilihan Umum Republik Indonesia Nomor: 179/PL.02-Kpt/0/KPU/III/2020 telah memenuhi unsur Pasal 5 Undang-Undang Nomor 30 Tahun 2014 tentang Administrasi Pemerintahan, baik dari segi asas legalitas, asas perlindungan terhadap hak asasi manusia maupun AUPB.

Untuk pembahasan mengenai kesesuaian AUPB dengan Penundaan Pemilihan Kepala Daerah pada masa pandemi Covid-19 di tahun 2020, baik dengan menggunakan instrumen yuridis Undang - Undang Nomor 6 Tahun 2020 maupun Keputusan Komisi Pemilihan Umum Republik Indonesia Nomor: 179/PL.02Kpt/01/KPU/III/2020 dilakukan berdasarkan asas kepastian hukum dan asas kecermatan yang biasa digunakan dalam yurisprudensi ataupun doktrin. Karena mengingat dalam teori hukum administrasi, AUPB tidak bersifat tertulis (dalam bentuk undang-undang) melainkan sumber umum hukum yang hidup (tidak tertulis).

\section{Daftar Pustaka}

\section{Buku}

Asshiddiqie, Jimly, Pengantar Ilmu Hukum Tata Negara, (Jakarta: Rajawali Pers, 2014).
Ibrahim, Johnny, Teori dan Metode Penelitian Hukum Normatif, (Malang: Boymedia Publishing, 2006).

M.Hadjon, et al, Philipus, Pengantar Hukum Administrasi Indonesia, (Yogyakarta: Gadjah Mada University Press, 1993).

Van Wijk , H.D., en Willem Konijnenbelt. Hoofdstukken van Adminitratief Recht, (s'Gravenhage: Vuga, 1995).

Yasin et al, Muhammad, Anotasi Undang-Undang Nomor 30 Tahun 2014 tentang Administrasi Pemerintahan,(Universitas Indonesia-Center for Study of Governance and Administrative Reform (UI-CSGAR), 2017).

\section{Makalah/Artikel/Prosiding/Hasil Penelitian}

M Hadjon, Philipus, Peradilan Tata Usaha Negara Dalam Konteks Undang-Undang Nomor 30 Tahun 2014 tentang Administrasi Pemerintahan, http://114.129.22.229:4070/ index.php/jurnalhukumperadilan/article/ view/74, Jurnal Hukum dan Peradilan, Volume 4 Nomor 1 tahun 2015, (diakses 25 Agustus 2020).

Muhammad Nasarudin, Tubagus, Asas Dan Norma Hukum Administrasi Negara Dalam Pembuatan Instrumen Pemerintahan, Jurnal Hukum Novelty, Vol. 7 No. 2, Agustus 2016, hal. 139-154, https://core.ac.uk/download/ pdf/ 295349133.pdf (diakses 25 Agustus 2020).

Wahyunadi, Yudi Martono, Kompetensi Absolut Pengadilan Tata Usaha Negara Dalam Konteks Undang-Undang Nomor 30 Tahun 2014 Tentang Administrasi Pemerintahan http://114.129.22.229:5555/index.php/ jurnalhukumperadilan/ article/view/50, Jurnal Hukum dan Peradilan, Volume 5 Nomor 1 tahun 2016, (diakses 25 Agustus 2020).

\section{Peraturan}

Undang-Undang Nomor 5 Tahun 1986 sebagaimana telah diubah dengan Undang-Undang Nomor Nomor 9 Tahun 2004 dan Undang-Undang Nomor 51 Tahun 2009 tentang Peradilan Tata Usaha Negara.

Undang-Undang Nomor 12 Tahun 2011 tentang Pembentukan Peraturan Perundang-undangan sebagaimana telah diubah dengan UndangUndang Nomor 15 Tahun 2019. 
Undang-Undang Nomor 30 Tahun 2014 tentang Administrasi Pemerintahan.

Undang - Undang Nomor 6 Tahun 2020 tentang tentang Penetapan Peraturan Pemerintah Pengganti Undang-Undang Nomor 2 Tahun 2020 Tentang Perubahan Ketiga Atasundang-Undang Nomor 1 Tahun 2015 Tentangpenetapan Peraturan Pemerintah Pengganti Undang-Undang Nomor 1 Tahun 2014 Tentang Pemilihan Gubernur,Bupati, dan Walikota Menjadi Undang-Undang menjadi Undang-Undang.
Peraturan Pemerintah Pengganti Undang-Undang Nomor 2 Tahun 2020 tentang Perubahan Ketiga atas Undang-Undang Nomor 1 Tahun 2015 tentang Penetapan Peraturan Pemerintah Pengganti Undang-Undang Nomor 1 Tahun 2014 tentang Pemilihan Gubernur, Bupati, dan Walikota Menjadi Undang-Undang.

\section{Internet}

www.kompas.com, 2020, https://www.kompas. com/global/read/2020/03/12/ 001124570/ who-umumkan-virus-corona-sebagaipandemi global? page=all, (diakses 13 Juli 2020) 